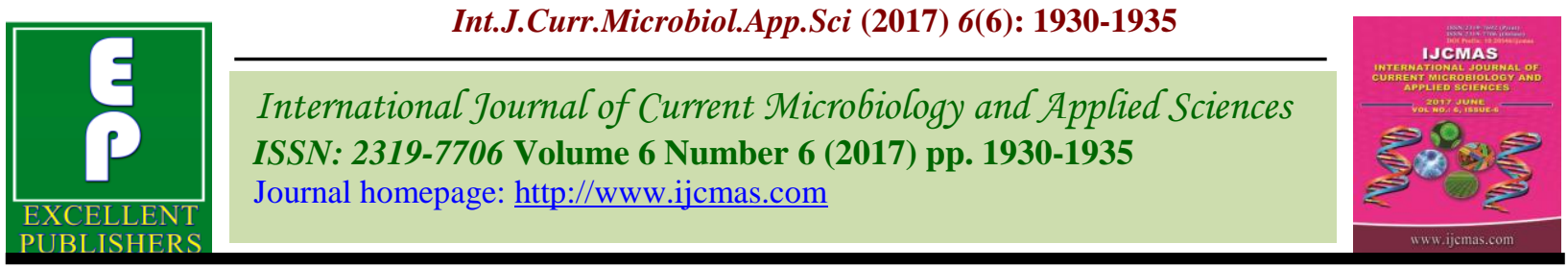

Original Research Article https://doi.org/10.20546/ijcmas.2017.606.225

\title{
Effect of Nitrogen and Sulphur on Growth and Yield of Hybrid Maize (Zea mays L.)
}

\author{
Mirwais Daoudi and Rajesh Singh* \\ Department of Agronomy, Sam Higginbottom University of Agriculture, Technology and \\ Sciences, Allahabad - 211007, U.P. India \\ *Corresponding author:
}

\begin{tabular}{|c|c|}
\hline & A B S T R A C T \\
\hline & An experiment was conducted at Crop Research Farm, Department of Agronomy, \\
\hline Keywords & out the effect levels of nitrogen and sulphur on growth and yield of hybrid maize (Zea \\
\hline $\begin{array}{l}\text { Hybrid maize, } \\
\text { Nitrogen levels, } \\
\text { Sulphur levels, } \\
\text { Yield parameters. }\end{array}$ & $\begin{array}{l}\text { mays L.). The experiment was laid out in RBD having } 12 \text { treatments replicated thrice and } \\
\text { it consisted of } 3 \text { levels of nitrogen viz. } 100 \mathrm{~kg} \mathrm{~N}^{-1} 120 \mathrm{~kg} \mathrm{~N} \text { and } 140 \mathrm{~kg} \mathrm{~N} \text { and } 4 \text { levels of } \\
\text { sulphur viz. control, } 15 \mathrm{~kg} \mathrm{~S} \mathrm{ha}^{-1}, 30 \mathrm{~kg} \mathrm{~S} \mathrm{ha}^{-1} \text { and } 45 \mathrm{~kg} \mathrm{~S} \mathrm{ha}^{-1} \text {. The experimental findings } \\
\text { record that the maximum plant height }(198.67 \mathrm{~cm}) \text {, maximum plant dry weight }(178.09 \mathrm{~g}) \text {, }\end{array}$ \\
\hline Article Info & Grain rows $\operatorname{cob}^{-1}(16.07)$ and grains row $^{-1}(30.15), 1000$ - grain weight $(238.67 \mathrm{~g})$ and grain \\
\hline $\begin{array}{l}\text { Accepted: } \\
\text { 23 May } 2017 \\
\text { Available Online: } \\
\text { 10 June } 2017\end{array}$ & $\begin{array}{l}\text { yield }\left(9717 \mathrm{~kg} \mathrm{ha}^{-1}\right) \text { were recorded in treatment } \mathrm{T}_{11}\left(140 \mathrm{~kg} \mathrm{~N} \mathrm{ha}^{-1}+30 \mathrm{~kg} \mathrm{~S} \mathrm{ha}^{-1}\right) \text { followed } \\
\text { by treatment } \mathrm{T}_{7}\left(120 \mathrm{kgNha}^{1}+30 \mathrm{~kg} \mathrm{~S}^{-1}\right) \text { and it was concluded that nitrogen and sulphur } \\
\text { significantly influenced the growth parameters and yield of hybrid maize and higher level } \\
\text { of sulphur i.e. } 45 \mathrm{~kg} / \text { ha increased the cost of cultivation and also had antagonistic effect on } \\
\text { yield attributes of maize. }\end{array}$ \\
\hline
\end{tabular}

\section{Introduction}

Maize (Zea mays L.) is one of the most important cereal crops, next to rice and wheat and is used as a food for men and feed for animals. This crop has been developed into a multi-dollar business in countries viz. Thiland, Tiwan, Singapore, Malaysia, USA, Canada and Germany, because of its potential as a value added product for export and a good food substitute (Mugalkhod et al., 2011). Maize is gaining immense importance on account of its potential uses in manufacturing starch, plastics, rayon, adhesive, dye, resins, boot polish etc. and due to this large uses it is rightly called a Miracle crop and also known as 'Queen of cereals' due to its high potential yield. In India, maize is grown in an area of 9.43 million hectares with production of $24.35 \mathrm{~m} \mathrm{t}$ and productivity of $2583 \mathrm{~kg} \mathrm{ha}^{-1}$ (Government of India, 2014). Maize yield is generally higher in high solar intensities, lower night temperature and lower pest infestation (Adesoji et al, 2013). Optimum plant density leads to better utilization of solar radiation resulting into corn dry matter accumulation and biomass production (Moosari et al., 2012). The production of maize in India is quite low as compared to the countries viz. Thiland, Tiwan, Singapore and USA. The probable reason may be due to nitrogen and sulphur 
deficiency of our soils. It has been reported by many workers that most of the Indian soils are deficient in sulphur.

Nitrogen is a vital plant nutrient and a major yield determining macronutrient for most of the cereals. It is very essential for plant growth, as it makes up 1 to $4 \%$ of dry matter of the plants. It is a major component of proteins and nucleic acids. It is also an essential constituent of chlorophyll and many other enzymes (Onasanyes et al., 2009). Thus, availability of nitrogen in sufficient quantity throughout the growing season is essential for optimum growth and production of maize.

Sulphur, nowadays is considered as the $4^{\text {th }}$ major plant nutrient after nitrogen, phosphorus and potassium (Nyborg and Bently, 1997). This nutrient helps the plant to perform many physiological functions like synthesis of sulphur containing amino acids viz. cysteine, cystine and methionine. It is also involved is various metabolic processes of plant. It is also a constituent of Glutathione, a compound supposed to be associated with the plant respiration and synthesis of essential oils. Sulphur also plays a vital role in chlorophyll formation. The plant requirement for sulphur is mainly responsible for nitrogen availability hence with the increasing rate of sulphur, the availability of nitrogen and it uptake increases (Metha et al., 2005). Keeping the above facts in view and to increase the production of maize in India, an experiment entitled "Growth and Yield of Hybrid Maize (Zea mays L.) as influenced by levels of Nitrogen and Sulphur was conducted at SHUATS, Allahabad( U. P ).

\section{Materials and Methods}

The experiment was conducted at CRF (Crop Research Farm), Department of Agronomy, SHUATS, Allahabad, U.P during kharif season of 2016. Geographically, the experimental site is located between $25^{\circ} 24^{\prime}$ $42^{\prime \prime}$ North latitude and $81^{0} 50^{\prime}$ 56" East longitude and at an altitude of $98 \mathrm{~m}$ above the mean sea level. The soil of the experimental field was sandy loam in texture having organic carbon $0.93 \%$, available nitrogen $190.3 \mathrm{~kg} \mathrm{ha}^{-1}$, available phosphorus $22.5 \mathrm{~kg} \mathrm{ha}^{-1}$, available potassium $87 \mathrm{~kg} \mathrm{ha}^{-1}$.The $\mathrm{pH}$ and EC of the soil was recorded as 7.5 and $0.27 \mathrm{~m}^{-1}$ respectively. The experiment was conducted in RBD (Randomized Block Design) comprising of 12 treatments each replicated thrice. There were 3 levels of nitrogen viz. 100,120 and $140 \mathrm{~kg} \mathrm{ha}^{-1}$ and 4 Sulphur levels viz. control, 15, 30 and $45 \mathrm{~kg} \mathrm{ha}^{-1}$. The variety of maize used was Champion 61(Hybrid) and the seeds were sown at a spacing of $60 \times 20$ $\mathrm{cm}$ using a seed rate of $20 \mathrm{~kg} \mathrm{ha}^{-1}$.

\section{Result and Discussions}

\section{Growth Attributes}

An appraisal of table 1 reveals that growth parameter differed significantly among treatments. The plant height, dry weight, LAI, length of cobs with and without husk recorded maximum values in treatment $\mathrm{T}_{11}(140 \mathrm{~kg} \mathrm{~N}$ $\mathrm{ha}^{-1}+30 \mathrm{~kg} \mathrm{~S} \mathrm{ha}^{-1}$ ) as $195.07 \mathrm{~cm}, 178.29 \mathrm{~g}$, $5.16,27.67 \mathrm{~cm}$ and $24.03 \mathrm{~cm}$ respectively followed by treatment $T_{7}$ which was found to be at par to treatment $\mathrm{T}_{11}$ except LAI.

The probable reason for attaining maximum values of aforesaid parameters with nitrogen @ $140 \mathrm{~kg} \mathrm{~N} \mathrm{ha}{ }^{-1}$ was because that nitrogen being major component of chlorophyll and proteins enhanced growth and development and hence produced plants with more leaf area and leaf area index (Kandif, 2013). The other reason may be due to better mineralization and availability of nitrogen to plants for plant metabolism which affects the physiological processes of the maize crop. 
Table.1 Growth and yield of hybrid maize as influenced by levels of nitrogen and sulphur

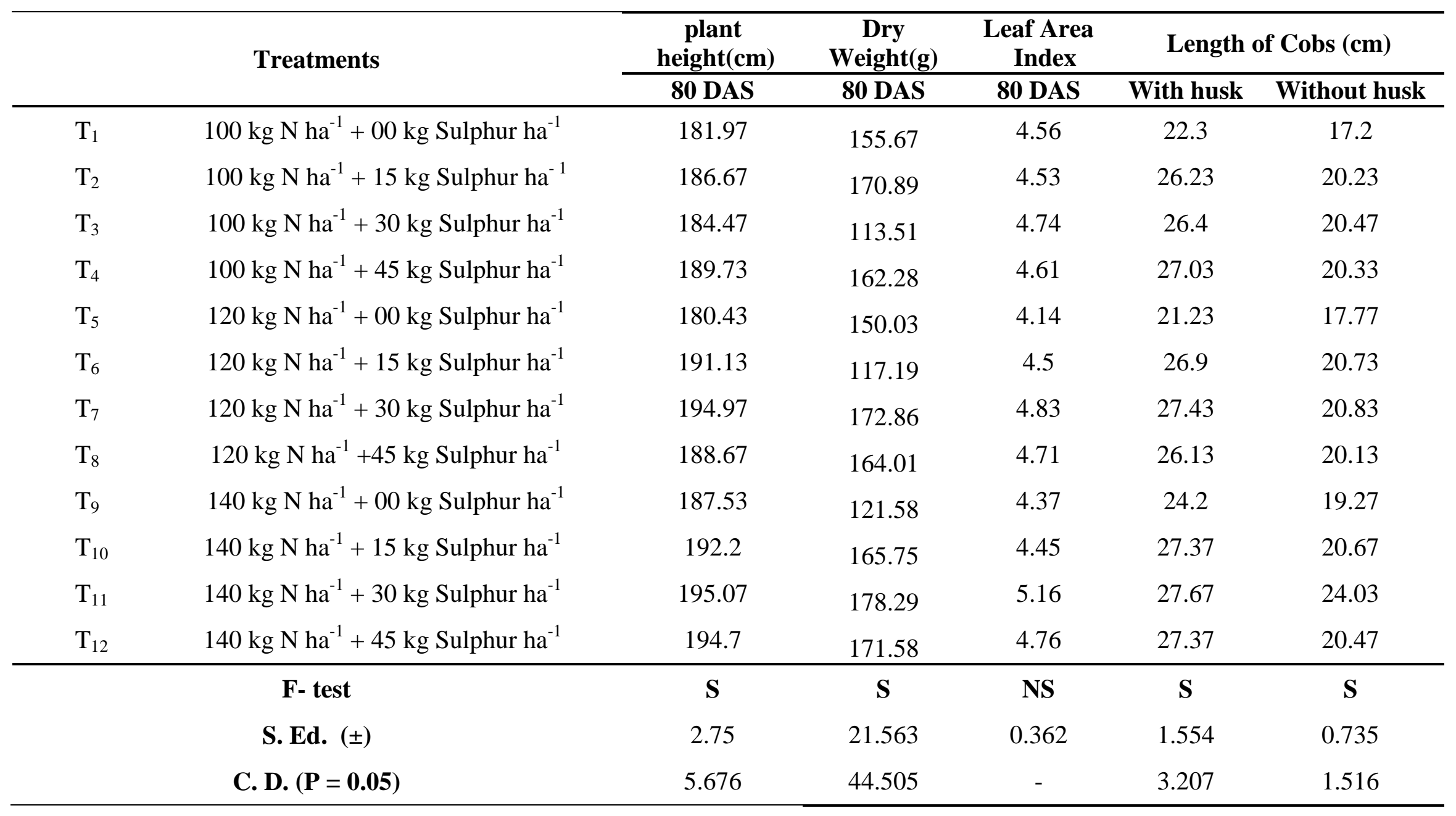


Table.2 Yield of hybrid maize as influenced by levels of nitrogen and sulphur

\begin{tabular}{|c|c|c|c|c|c|}
\hline & Treatments & $\begin{array}{c}\text { Grain } \\
{\text { Rows } \operatorname{Cobs}^{-1}(\text { No. })}\end{array}$ & $\begin{array}{c}\text { Grains } \\
\operatorname{Rows}^{-1}(\text { No. }) \\
\end{array}$ & $\begin{array}{c}1000 \text { grain } \\
\text { weight }(g)\end{array}$ & $\begin{array}{l}\text { Grain yield } \\
\quad\left(\mathrm{kg} \mathrm{ha}^{-1}\right)\end{array}$ \\
\hline $\mathrm{T}_{1}$ & $100 \mathrm{~kg} \mathrm{~N} \mathrm{ha}^{-1}+00 \mathrm{~kg}$ Sulphur ha ${ }^{-1}$ & 15 & 28.87 & 188.67 & 6858.67 \\
\hline $\mathrm{T}_{2}$ & $100 \mathrm{~kg} \mathrm{~N} \mathrm{ha}^{-1}+15 \mathrm{~kg}$ Sulphur ha ${ }^{-1}$ & 14.33 & 27.13 & 215.33 & 7528.00 \\
\hline $\mathrm{T}_{3}$ & $100 \mathrm{~kg} \mathrm{~N} \mathrm{ha}{ }^{-1}+30 \mathrm{~kg}$ Sulphur ha ${ }^{-1}$ & 14.13 & 29.60 & 194.00 & 7636.00 \\
\hline $\mathrm{T}_{4}$ & $100 \mathrm{~kg} \mathrm{~N} \mathrm{ha}^{-1}+45 \mathrm{~kg}$ Sulphur ha ${ }^{-1}$ & 14.87 & 29.93 & 184.00 & 7655.33 \\
\hline $\mathrm{T}_{5}$ & $120 \mathrm{~kg} \mathrm{~N} \mathrm{ha}^{-1}+00 \mathrm{~kg}$ Sulphur ha ${ }^{-1}$ & 14.47 & 28.80 & 212.67 & 7152.67 \\
\hline $\mathrm{T}_{6}$ & $120 \mathrm{~kg} \mathrm{~N} \mathrm{ha}^{-1}+15 \mathrm{~kg}$ Sulphur ha ${ }^{-1}$ & 14.6 & 28.27 & 214.00 & 7732.67 \\
\hline $\mathrm{T}_{7}$ & $120 \mathrm{~kg} \mathrm{~N} \mathrm{ha}^{-1}+30 \mathrm{~kg}$ Sulphur ha ${ }^{-1}$ & 16.05 & 30.67 & 218.67 & 8483.33 \\
\hline $\mathrm{T}_{8}$ & $120 \mathrm{~kg} \mathrm{~N} \mathrm{ha}^{-1}+45 \mathrm{~kg}$ Sulphur ha ${ }^{-1}$ & 15.20 & 29.13 & 210.67 & 7419.33 \\
\hline $\mathrm{T}_{9}$ & $140 \mathrm{~kg} \mathrm{~N} \mathrm{ha}^{-1}+00 \mathrm{~kg}$ Sulphur ha ${ }^{-1}$ & 14.73 & 26.77 & 202.67 & 7175.33 \\
\hline $\mathrm{T}_{10}$ & $140 \mathrm{~kg} \mathrm{~N} \mathrm{ha}{ }^{-1}+15 \mathrm{~kg}$ Sulphur ha ${ }^{-1}$ & 14.60 & 29.40 & 208.00 & 7167.33 \\
\hline $\mathrm{T}_{11}$ & $140 \mathrm{~kg} \mathrm{~N} \mathrm{ha}{ }^{-1}+30 \mathrm{~kg}$ Sulphur ha ${ }^{-1}$ & 16.07 & 31.07 & 238.67 & 9717.33 \\
\hline $\mathrm{T}_{12}$ & $140 \mathrm{~kg} \mathrm{~N} \mathrm{ha}^{-1}+45 \mathrm{~kg}$ Sulphur ha ${ }^{-1}$ & 15.47 & 30.13 & 216.00 & 7896.67 \\
\hline & F- test & NS & NS & $\mathbf{S}$ & $\mathbf{S}$ \\
\hline & S. Ed. $( \pm)$ & 0.758 & 2.193 & 13.656 & 485.026 \\
\hline & C. D. $(P=0.05)$ & - & - & 28.187 & 1001.094 \\
\hline
\end{tabular}


It was also observed that sulphur levels had non-significant effect on growth parameters due to the fact that sulphur has no role in vegetative growth as it is a qualitative nutrient. However, length of cobs with and without husk recorded maximum values in treatment $\mathrm{T}_{11}$ may be due to optimum availability of nitrogen and sulphur and better translocation of these nutrients to the reproductive parts. These findings are in accordance to those of Rasheed et al., (2004), Jeet et al., (2012), Qahar and Ahmad (2015) and Alam et al., (2003).

\section{Yield parameters}

\section{Grains row ${ }^{-1}$ and grain rows $\operatorname{cob}^{-1}$}

A perusal of table 2 reveals that number of grains rows $\mathrm{cob}^{-1}$ and grains row ${ }^{-1}$ show nonsignificant effect with respect to different levels of nitrogen and sulphur. However, maximum grain rows per cob (16.07) and grains row $^{-1}$ (31.07) was recorded in treatment $\mathrm{T}_{11}$ followed by treatment $\mathrm{T}_{7}(16.05$ and $30.67)$ respectively. This may be due to larger cob size, proper pollination, translocation of sugars and starch and finally proper grain set due to higher nitrogen fertilizer dose and high nitrogen use efficiency and sulphur provides better nutrition to reproductive parts being a qualitative nutrient. These findings are in conformity to recommendation of Alam et al., (2003).

\section{0 grain weight}

A critical review of the table 2 clearly depicts that there was significant influence of nitrogen and sulphur on test weight of maize hybrid under study and maximum test weight (238.67g) was recorded in treatment $\mathrm{T}_{11}$ followed by treatment $\mathrm{T}_{7}(218.67 \mathrm{~g})$ and was found to be at par to treatment $T_{11}$. This increase in test weight was due to better seed setting and better translocation of sugars and starch as a result of increasing levels of nitrogen and sulphur application which enhanced crop growth rate, NAR and dry weight plant ${ }^{-1}$, which ultimately increased test weight. Similar findings have also been reported by Rasheed (2003).

\section{Grain Yield}

An appraisal of table 2 reveals that there was significant effect of treatments on grain yield of maize. Maximum grain yield $(9717.33 \mathrm{~kg}$ $\mathrm{ha}^{-1}$ ) was recorded in treatment $\mathrm{T}_{11}$ followed by treatment $\mathrm{T}_{7}\left(8483.33 \mathrm{~kg} \mathrm{ha}{ }^{-1}\right)$. The increase in grain yield/ha as a result of increasing nitrogen and sulphur application is attributed to enhanced CGR, NAR and DWP which ultimately increased grain number ear ${ }^{-1}$ and grain weight ear $^{-1}$. The other reason for increase in grain yield/ha with successive increase in nitrogen and sulphur was due to more leaf area and dry weight plant ${ }^{-1}$. It was also observed that sulphur had significant influence on grain yield at $30 \mathrm{~kg} \mathrm{ha}^{-1}$ than 45 $\mathrm{kg} \mathrm{ha}^{-1}$ as it shows antagonistic effect thus reduced grain yield. These findings corroborate with the results of Shiraji et al., (2000) and Pandey et al., (2000).

In conclusion, based on the above findings it can be concluded that an application of $140 \mathrm{kgN} \mathrm{ha}^{-1}+30 \mathrm{~kg}$ of $\mathrm{S} \mathrm{ha}^{-1}$ is the best combination of nitrogen and sulphur for obtaining better growth attributes and higher yield of hybrid maize and can be recommended to the farmers of Allahabad region for sustaining productivity and profitability of maize.

\section{References}

Agriculture Statistics at a Glance, Ministry of Agriculture, GOI. Oxfrd Press pp-177199.

Alam, Mh, Morshed., Islam, Md, Nazrul., Md, shah., Rahman, $M$ and Howue, M.(2003). Effects of sulphur and 
nitrogen on the yield and seed Quality of maize (cv. Barnali) online journal of biological sciences 3 (7): 643-654, ISSN 1608-4217.

Jeet, S., Singh, J. P., Kumar, R., Prasad, R. K., Kumar, P.,Kumari, A \&Prakash, P.(2012). Effect of Nitrogen and Sulphur Levels on Yield, Economics andQuality of QPM Hybrids under Dryland Condition of Eastern UttarPradesh, India.Journal of Agricultural Science; Vol. 4, No. 9; ISSN 1916-9752.

KandilEEE (2013).Response of some maize hybrids (Zea mays L.) to different levels of nitrogenous fertilization.J. of App. Sci. Res. 9(3): 1902-1908.

Pandey, A.K., V.P Mani and R.D Singh.(2000). Effect of rate of nitrogen and time of application on yield and economics of baby corn (Zea mays L.). Indian J. Ahron.,338-43.

Qahar, A., and Ahmad, B. (2015).Macro Nutrients (Nitrogen and Sulfur) Role in Phenology and Physiology of Different
Corn Hybrids under Agro Climatic Conditions of Peshawar, Pure Appl. Bio., 4(1): 89-96.

Rasheed M, Hussain A \&Mahmood T (2003).Growth analysis of hybrid maize as influenced by planting techniques and nutrient management.Intl. J. of Agric. \& Bio. (2): 169-171.

Rasheed, M., Ali, H., and Mahmood, T.(2004). Impact of Nitrogen And Sulfur Application on Growth and Yield of Maize (Zea mays L.) Crop. Journal of Research (Science), Vol.15, No.2, pp. 153-157.

Sepat, A., \& Kumar, A. (2007). Influence of irrigation and nitrogen management on yield and economics of maize(Zea mays L.). Crop Res.(Hisar)., 33(1/3), 50-52.

Shiraji, S.M., M.S.U. Talukder, M.A. Hossain, M. Niazuddin and M.A. Samad.(2000).Effect of irrigation regices and nitrogen levels on the performance of maize.Bangladesh Agril.Sci., 27: 271.

\section{How to cite this article:}

Mirwais Daoudi and Rajesh Singh. 2017. Effect of Nitrogen and Sulphur on Growth and Yield of Hybrid Maize (Zea mays L.). Int.J.Curr.Microbiol.App.Sci. 6(6): 1930-1935. doi: https://doi.org/10.20546/ijcmas.2017.606.225 